\title{
THE ROLE OF THE REMBITAN ANCIENT MOSQUE IN THE PEMOLE PROCESSION IN REMBITAN VILLAGE
}

\section{Lalu Iman Novian Wahyudi, Antariksa, Johanes Parlindungan}

Brawijaya University, Indonesia

Email: imanwahyudi555@yahoo.co.id, antariksa@ub.ac.id, johannes@ub.ac.id

\begin{tabular}{|c|c|}
\hline ARTICLE INFO & ABSTRACT \\
\hline $\begin{array}{l}\text { Received: } \\
\text { January, 26 } \\
2022 \\
\text { Revised: } \\
\text { February, 17th } \\
2022 \\
\text { Approved: } \\
\text { February, } 18^{\text {th }} \\
2022\end{array}$ & $\begin{array}{l}\text { The Rembitan village is one of the villages in Pujut Subdistrict } \\
\text { that still maintains the traditional traditions and culture of } \\
\text { the Sasak Tribe. This tradition has built a system of life for the } \\
\text { Sasak people who are believed to bring good for themselves } \\
\text { and the group. This tribe is a good community and that has } \\
\text { been oriented to Ancient Mosque Rembitan which builds the } \\
\text { existing traditions and culture. At this time the tradition of } \\
\text { this tradition began to decrease in demand and the } \\
\text { understanding of its successors related to polishing culture } \\
\text { began to decrease due to cultural acculturation. For this } \\
\text { reason, there needs to be a continuity of cultural knowledge } \\
\text { for the next generation to ensure the preservation of the } \\
\text { culture and uniqueness of the region. The purpose of this } \\
\text { research is to describe the value contained in polishing } \\
\text { culture so that the next generation can learn and understand } \\
\text { the meaning and purpose of each tradition carried out by its } \\
\text { predecessors. This study shows that the role of the Ancient } \\
\text { Mosque of Rembitan is very visible and orientates every } \\
\text { activity in Rembitan Village. This is manifested in the form of } \\
\text { beliefs, attitudes, and visible symbols such as settlements and } \\
\text { indigenous polishing activities. The results of the analysis } \\
\text { showed that the role of the Ancient Rembitan mosque was as } \\
\text { a space or container for the people of Rembitan Village in } \\
\text { carrying out every process of life, both in the form of physical } \\
\text { and cultural activities (polishing). }\end{array}$ \\
\hline
\end{tabular}

KEYWORDS Ancient Mosque of Rembitan, Polishing, Rembitan Village 
Lalu Iman Novian Wahyudi, Antariksa, Johanes Parlindungan

\begin{tabular}{lll}
\hline (c) (i) (9) & This work is licensed under a Creative Commons \\
Attribution-ShareAlike 4.0 International
\end{tabular}

\section{INTRODUCTION}

In terms of belief, before knowing Islam, the Sasak people adhered to a belief called Sasak Boda (Rahman \& Bramantyo, 2020). Boda is not a Buddhist teaching. The Boda religion of the Sasak tribe is a religion characterized by worshiping the spirits of their own ancestors (Zuhdi, 2018). The influence of Hinduism on the island of Lombok was marked by the arrival of the Majapahit Kingdom which brought Hindu-Buddhist teachings (Mustika, 2017). After the arrival of the Majapahit Kingdom, the Sasak people began to recognize Hindu teachings (Ramdhani, Busro, \& Wasik, 2020). At the end of the 16th century Sunan Giri brought Islamic teachings to the island of Lombok (Budiwanti, 2014). After that the development of the Sasak belief system began to develop and was divided into three main groups, namely Boda, Wetu Telu and Islam (Wetu Lima) (Aniq, 2011).

The Sasak people are one of the tribes who uphold social values in social life, because almost all life activities are carried out by mutual cooperation (Ribut, Triguna, \& Suija, 2019). This is one of the characteristics of the Sasak Tribe, a style of life, where everyone has their own responsibility in launching traditional events or other community activities (Suastra \& Pujani, 2021).

Sade Village is a famous village because it is on a strategic route to the tourist route to Kuta Beach, Central Lombok Regency (Siregar, 2018). Sade Village is famous for still upholding the value of local wisdom of the Sasak tribe both in terms of customs and living culture (Firdaus, n.d.). The pattern of activity and the meaning of space is formed from the human character itself and the culture that exists in that place (Ganshina, Babaeva, Medved, Levina, \& Kamenets, 2019). The character of the traditional villages in Central Lombok Regency is inseparable from the belief system adopted, namely Islam and the main livelihood of the Sasak people, namely farming (Tohri, Habibuddin, \& Rasyad, 2020). For example, every traditional activity such as drawing, ngurisan, and death ceremonies carried out will always involve traditional elders or in this case a kiyai who is an expert in religious knowledge.

On the island of Lombok, there are three ancient mosques which are relics of the kingdom and the spread of Islam on the island of Lombok in the past (Jamaludin, 2018). Rembitan Ancient Mosque is one of the oldest mosques located in Rembitan Village. This mosque is estimated to have been established in the 16th century and was founded by datoq nyatoq, a guardian who has the task of spreading Islam on the island of Lombok. This mosque is not much different from other mosques that function as other places of worship, what distinguishes this mosque apart from being religiously culturally has a high level of sacredness which is evidenced by the existence of community traditions such as massaging done only on Wednesdays or when someone wants to fulfill a vow. only on wednesdays. In addition, this mosque has a mangku or respected traditional elder who is in charge of every ritual or cultural activity within the Rembitan Ancient Mosque (Harnish, 2021).

The nyatoq tomb is the tomb of the nyatoq guardian, a guardian who spreads Islam on the island of Lombok. This tomb building is located on a hill in Rembitan Village and has been designated as a cultural heritage area (Siregar, 2018). This tomb has an important position in people's lives, especially in matters related to belief, they believe the existence of the guardian nyatok brings blessings to the community because it has

The Role of the Rembitan Ancient Mosque in the Pemole Procession in Rembitan Village 
brought Islamic life. The level of sacredness of this tomb can be seen from the activities of the people who come for pilgrimages every Wednesday which have been carried out from generation to generation until now (Sesady, Wahid, Laupa, Bedong, \& Syatar, 2021)

Sade is one of the hamlets located in Rembitan Village, Pujut District, Central Lombok Regency. Sade Hamlet is a tourism icon in Central Lombok Regency, with its unique cultural spatial layout and still strong customs so that it becomes a special attraction for tourists. Physically (real) Dusun Sade is the embodiment of the cultural customs found in the Sasak gumi (land) which are believed to be passed down from generation to generation by the Sasak people. Starting from the selection of residential locations (located in the hills), oriented towards the direction of sunrise and sunset, and residential (settlement) spatial planning which has its own meaning and meaning in its placement.

The existence of culture provides an overview of the area and the people in the area. Until now, the concept of regional development has a uniqueness that can be seen from the culture it has. Culture is a necessity for people who have been identified as one in everyday life. The stronger the cultural character found in the community, the identification of a person with the area will become easier and become an experience. This is one of the heirlooms that has been formed from the past and really gives meaning to the Sasak community itself. A space with a sense of identity that can be felt is created from a culture of character. The spatial setting that has been done by the community will be read as a culture when it is interpreted in depth and is well correlated by the community life.

\section{RESEARCH METHOD}

According to Spreadly (2007:3) ethnography is the efforts made in describing culture with the aim of understanding the view of life seen from the point of view of the natives. Ethnography is a study of how people live and behave in the culture they believe in (Endraswara, 2017: 50).

Ethnographic research places great emphasis on direct involvement in the field to gain views and a sense of the culture of a society. Based on this, ethnography can also be said to provide an empirical and theoretical approach at the same time with the aim of not only being in the form of a description but also a cultural analysis that comes from intense field work.

\section{RESULT AND DISCUSSION}

From the results of the study that the role of the Rembitan Ancient Mosque and the Nyatoq Tomb is very important because it is the center of traditional community activities.

\section{Rembitan Ancient Mosque}

The Rembitan Ancient Mosque is a mosque building that stands on a hill in Rembitan Satu Hamlet, Rembitan Village which was built around the 16th century by a guardian named Wali Nyatok. This guardian has the task of spreading Islam on the island of Lombok by establishing this mosque at first as his house and then used by the community as a place of worship or like a mosque in general. 


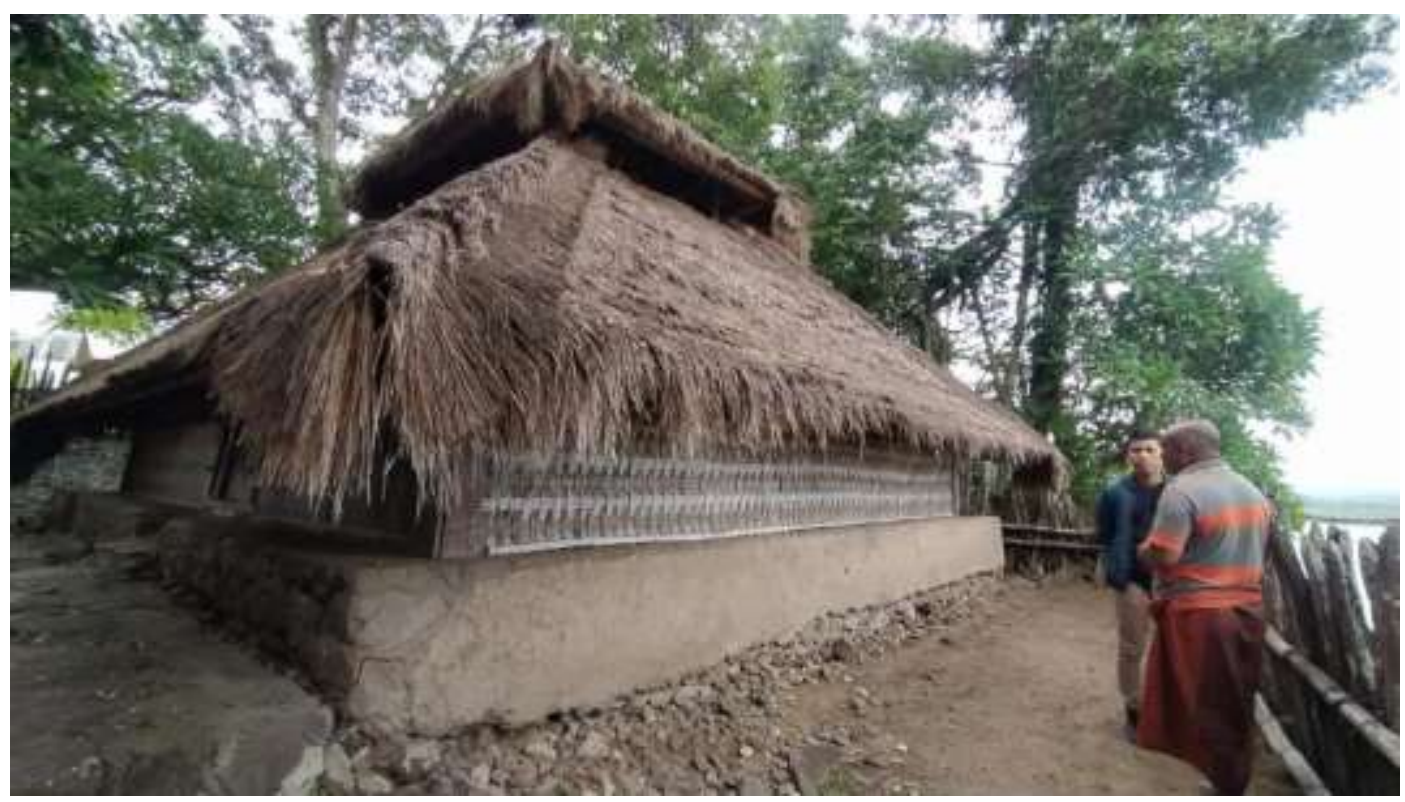

Figure 1: Rembitan Ancient Mosque

This mosque has the character of a roof like a punden terraced upwards and made of straw, has four main supporting pillars made of wood, walls made of bamboo fences, floors covered with soil and foundations made of stone and clay layers. The people of Rembitan Village really maintain the sacredness of this mosque with several activities carried out such as the pemole tradition. Pemole means return. Pemole is a series of mandatory traditions carried out by the people in Rembitan Village. The pemole tradition consists of several rituals, namely poteq porridge, beaq porridge, mulud, fasting, and hari raye.

These rituals have their own implementation time, where the unit of time used is the hijri month (Islamic month). Poteq porridge is performed on 10 Muharram, Beaq porridge on 9 Safar, Mulud on 12 Rabi'ul Awal, fasting in Ramadan, and Raye on 1 Shawwal.

In addition to the mosque, there is also a tani bale which plays an important role in the pemole procession. Bale tani is a traditional house building for the Sasak people on the island of Lombok. In the ancient mosque area there are two bale tani, namely the bale tani which is inhabited by the caretaker of the Ancient Rembitan mosque, Mr. Nur Alim and the bale tani, which is inhabited by the mangku (traditional elder) of the Rembitan Ancient Mosque, namely Lalu Ginsir. 

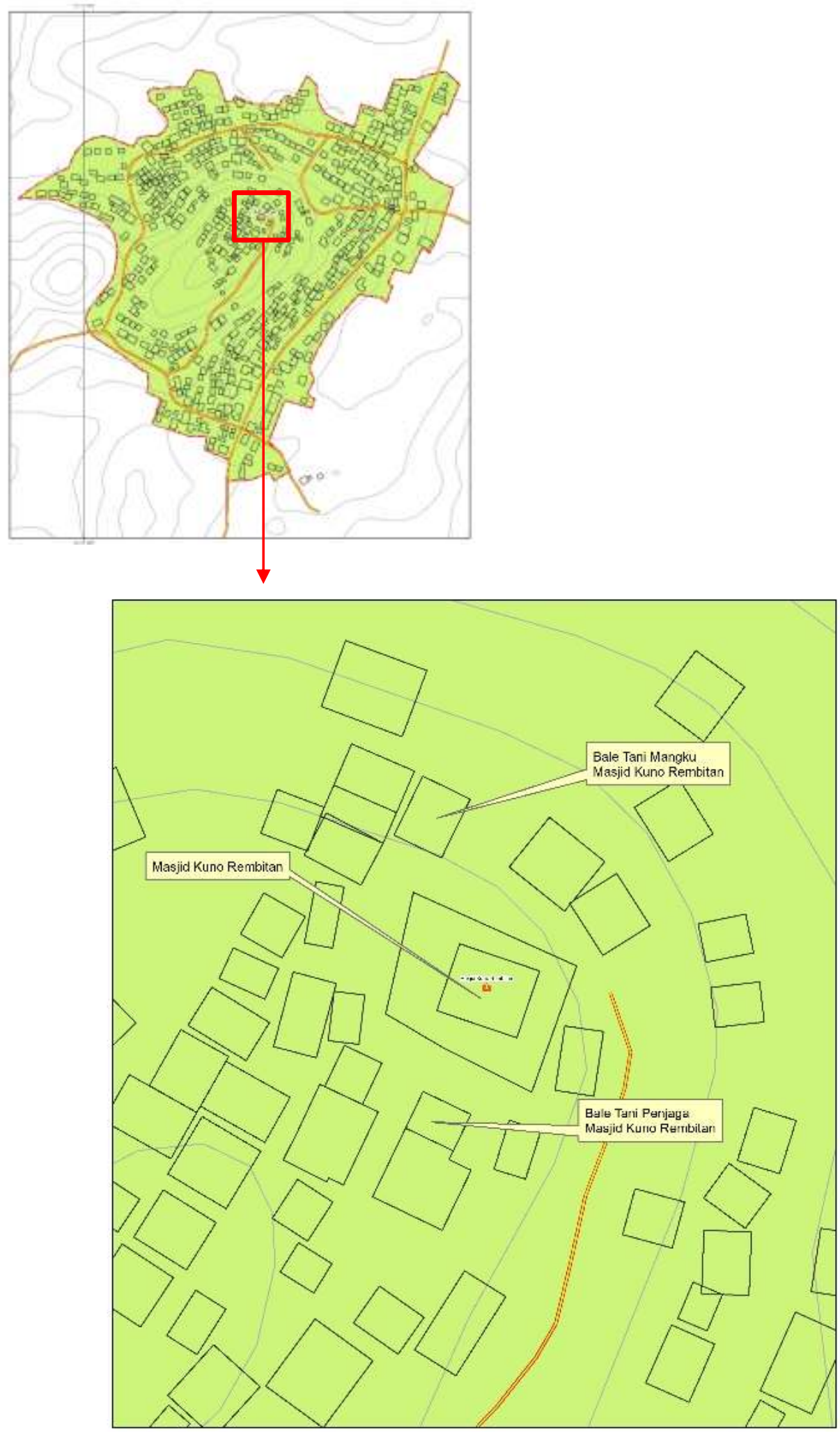

Figure 2: Rembitan Ancient Mosque area map 


\section{Lalu Iman Novian Wahyudi, Antariksa, Johanes Parlindungan}

Based on the picture above, it can be seen that the Rembitan Ancient Mosque is in the middle of a community settlement, where the mosque is the center of community orientation in living. In addition, if viewed from the contour line, the Rembitan Ancient Mosque is located in a hilly area and the mosque building is at the top of the hill.

Based on the prevailing customary norms, the pemole tradition is in the bale tani and in the Rembitan Ancient mosque. If the Rembitan Ancient Mosque is the center for pemole activities, the sub-center is the tani bale. Bale tani plays a major role in the preparation of the pemole event, such as the preparation of the pesajiq which will be brought to the Rembitan Ancient Mosque to be served to traditional stakeholders, traditional leaders, religious leaders, and the community.

Figure 03: the direction of community movement in the pemole procession.

At a macro level, the movement of the community for each pemole procession is to go to the mosque (to the top), because the mosque is on top of the hills. The position of the mosque is above the hills and higher than other buildings has its own meaning. The top, height, and peak are symbols of sacredness, so what is in that place is a place to worship or a place to get closer to God.

Figure 04: the direction of community movement in the micro-pole process

The red arrow is the first movement made by the community towards the bale tani which is inhabited by Lalu Ginsir (the ancient Rembitan mosque bowl). This movement is carried out by mothers who are not in a condition of menstruation (holy) to cook and prepare pesajiq (food dishes) which will be served during the pemole event. This movement is carried out the day before the pemole event takes place.

The blue arrow is the direction of the movement of the community when the implementation of pemole takes place. Here, after the community has prepared all the necessities for the pemole pesajiq-pesajiq tradition that has been made, it is finally brought to the Rembitan Ancient Mosque as a dish to be consumed together (begebung).

The series of pemole events are basically an event as a form of gratitude for the gifts that Allah SWT has given to the entire community of Rembitan Village through the karomah of the Wali Nyatoq, the guardian who founded and resides in the Rembitan Ancient Mosque.

Overall the Rembitan Ancient Mosque is a sacred place for the community because it has historical values, cultural values (traditions), and religious values because this mosque is one of the places of worship for the people of Rembitan Village. In addition, this mosque acts as a center for traditional activities that take place in Rembitan Village.

Symbolically, this mosque is a symbol of human obedience in worship and the binding of human relations with God, that whatever is done is with a fixed intention to Allah or lillahita'ala.

\section{CONCLUSION}

Culture basically has built the character of society and provided knowledge of the good and the bad in living a life. This is what makes culture for the Sasak people on the island of Lombok, especially in Rembitan Village, which has an important role and is even used as a norm in acting and behaving. 
The pemole tradition is a traditional activity that reflects the community itself. What is in the community will be reflected into a series of traditions which start from poteq porridge to raye day. The series of pemole traditions is an illustration of how humans are formed from semen (poteq) which is processed in the womb and born pure (fitri).

The Rembitan Ancient Mosque is the center of pemole activities. In addition, this mosque also acts as an orientation for settlements around the mosque. It can be concluded that the mosque acts as a center (core) for the people of Rembitan Village, where this center consists of a center for cultural activities and a center for physical orientation (settlement) both.

\section{REFERENCES}

Aniq, Ahmad Fathan. (2011). Lombok Islam In The Eyes Of Anthropologists. Al Qalam, 28(2), 197-216.

Budiwanti, Erni. (2014). 5 The Purification Movement in Bayan, North Lombok: Orthodox Islam vis-à-vis Religious Syncretism. In Between Harmony and Discrimination: Negotiating Religious Identities within Majority-Minority Relationships in Bali and Lombok (pp. 144-162). Brill.

Firdaus, Laras. (n.d.). INTEGRATING LOCAL WISDOM OF SASAK TRIBE IN ECOLOGY LEARNING TO DEVELOP SCIENTIFIC ATTITUDE.

Ganshina, Galina Vasilievna, Babaeva, Elena Vyacheslavovna, Medved, Eleonora Iliinichna, Levina, Irina Dmitrievna, \& Kamenets, Alexander Vladlenovich. (2019). The basics of the specialist job profile diagram related to the field of socio-cultural activities. In Humanities \& Social Sciences Reviews (Vol. 7). GIAP Journals.

Harnish, David D. (2021). Change and Identity in the Music Cultures of Lombok, Indonesia. Brill.

Jamaludin, Jamaludin. (2018). Salut As A Gate For The Coming Of Islam In Lombok: Archaeological Analysis Of The Ancient Mosque In North Lombok. Heritage of Nusantara: International Journal of Religious Literature and Heritage, 7(1), 46-78.

Mustika, I. Ketut Cameng. (2017). Ḉiwa-Buddha doctrine implementation in clergy symbol towards Hindu society at Lombok. International Research Journal of Management, IT and Social Sciences, 4(2), 87-95.

Rahman, Irham, \& Bramantyo, Rizki Yudha. (2020). Legal protection against the existence of" Wetu Telu" traditional society against law number 11/2020 concerning work creation (omnibus law). International Research Journal of Management, IT and Social Sciences, 8(1), 19-24.

Ramdhani, Fajri Zulia, Busro, Busro, \& Wasik, Abdul. (2020). The Hindu-Muslim Interdependence: A Study of Balinese Local Wisdom. Walisongo: Jurnal Penelitian Sosial Keagamaan, 28(2), 195-218.

Ribut, Gusti Ayu Santi Patni, Triguna, Ida Bagus Gde Yudha, \& Suija, I. Wayan. (2019). Didactic strategy of wetu telu cultural heritage on sasak tribe. International Journal of Linguistics, Literature and Culture, 5(3), 9-17.

Sesady, Muliati, Wahid, Abdul, Laupa, Rukiah, Bedong, Muhammad Ali Rusdi, \& Syatar, Abdul. (2021). BELIEF SYSTEM IN BULU NENE: RELATION TO ZIARAH RITUAL TRADITION IN PINRANG DISTRICT, INDONESIA. PalArch's Journal of Archaeology of Egypt/Egyptology, 18(4), 1887-1896. 


\section{Lalu Iman Novian Wahyudi, Antariksa, Johanes Parlindungan}

Siregar, Andi Harapan. (2018). Conservation and re-development of sade traditional kampong at Rambitan village with local approach and cultural landscape. IOP Conference Series: Earth and Environmental Science, 126(1), 12079. IOP Publishing.

Suastra, I. W., \& Pujani, N. M. (2021). Local wisdom in Lombok island with the potential of ethnoscience for the development of learning models in junior high school. Journal of Physics: Conference Series, 1816(1), 12105. IOP Publishing.

Tohri, Ahmad, Habibuddin, H., \& Rasyad, Abdul. (2020). Sasak People's Resistance Against Mataram-Karangasem and Dutch Colonial Rulers: The Role of Tuan Guru Umar Kelayu. In Journal of Asian Social Science Research (Vol. 2).

Zuhdi, Muhammad Harfin. (2018). Wetu Telu in Bayan Lombok: Dialectic of Islam and Local Culture. Kawalu: Journal of Local Culture, 5(2), 85-106. 